\title{
Erratum to: Haematospirillum jordaniae gen. nov., sp. nov., isolated from human blood samples
}

B. W. Humrighouse $\cdot$ B. D. Emery •

A. J. Kelly • M. G. Metcalfe · J. Mbizo •

J. R. McQuiston

Published online: 9 April 2016

(C) Springer International Publishing Switzerland 2016

\section{Erratum to: Antonie van Leeuwenhoek (2016) 109:493-500 \\ DOI 10.1007/s10482-016-0654-0}

The author has noticed that some minor details including type strain culture collection codes were missing in the original publication of the article. The corrected protologue is given below.

Description of Haematospirillum gen. nov.

Haematospirillum (Hae.ma.to.spi.ril'lum. Gr. n. haima -atos, blood; L. n. spira, a spiral; N.L. neut.

The online version of the original article can be found under doi:10.1007/s10482-016-0654-0.

B. W. Humrighouse $(\bowtie) \cdot$ B. D. Emery ·

A. J. Kelly · J. R. McQuiston

Special Bacteriology Reference Laboratory, Bacterial Special Pathogens Branch, Division of High Consequence Pathogens and Pathology, Centers for Disease Control and Prevention, Atlanta, USA

e-mail: Bhumrighouse@cdc.gov

M. G. Metcalfe

Infectious Diseases Pathology Branch, Division of High Consequence Pathogens and Pathology, Centers for Disease Control and Prevention, Atlanta, USA

\section{J. Mbizo}

Department of Public Health, Clinical and Health Sciences, College of Science, Engineering and Health, University of West Florida, Pensacola, USA dim. n. spirillum, a small spiral; N.L. dim. neut. n. Haematospirillum, a small spiral from blood).

Cells are Gram-negative, oxidase positive, and catalase positive. Cells are motile, helical in shape and exhibit bipolar flagella. Major fatty acids are $\mathrm{C}_{16: 0}, \mathrm{C}_{16: 1} \omega 7 \mathrm{c}$ and $\mathrm{C}_{18: 1} \omega 7 \mathrm{c}$. The predominant ubiquinone is Q-10. The major polar lipids are phosphatidylethanolamine, phosphatidylglycerol and aminolipids. The DNA $\mathrm{G}+\mathrm{C}$ content of the type strain of the type species is $49.9 \%$. A member of the order Rhodospirillales, family Rhodospirillaceae. The type species is Haematospirillum jordaniae.

Description of Haematospirillum jordaniae sp. nov.

Haematospirillum jordaniae (jor.da'ni.ae. N.L. gen. n. jordaniae, named in honour of the late Jean Jordan).

In addition to those given in the genus description, the organism exhibits the following properties. On Heart Infusion Agar supplemented with $5 \%$ rabbit blood, colonies are circular, low convex, entire, grey, and $1 \mathrm{~mm}$ in diameter after $48 \mathrm{~h}$ of incubation at $35{ }^{\circ} \mathrm{C}$. Cells are approximately $1.6 \mu \mathrm{M}$ in length and $0.1-0.25 \mu \mathrm{M}$ in width. Positive for hydrogen sulfide production. Negative for utilisation of urea, nitrate reduction and tryptophan conversion to indole. In the API ZYM test, positive for alkaline phosphatase, esterase (C4), esterase lipase (C8) and acid phosphatase. Negative for lipase (C14), valine arylamidase, cystine arylamidase, trypsin, $\alpha$-chymotrypsin, 
Naphthol-AS-BI-phosphohydrolase, $\alpha$-galactosidase, $\beta$-galactosidase, $\beta$-glucuronidase, $\alpha$-glucosidase, $\beta$ glucosidase, $N$-acetyl- $\beta$-glucosaminidase, $\alpha$-mannosidase, and $\alpha$-fucosidase.
The type strain, H5569 ${ }^{\mathrm{T}}\left(=\mathrm{DSM}^{\mathrm{T}} 28903=\mathrm{CCUG}\right.$ $66838^{\mathrm{T}}$ ), was isolated from a human blood sample. The 16S rRNA sequence for strain $\mathrm{H} 5569^{\mathrm{T}}$ has been deposited in GenBank under Accession Number KM083603. 